\title{
EMILIO ORTEGA ARJONILLA, UNA COMPLICIDAD MARAVILLOSAMENTE INEVITABLE
}

\author{
Francisco GARCÍA MARCOS
}

Director

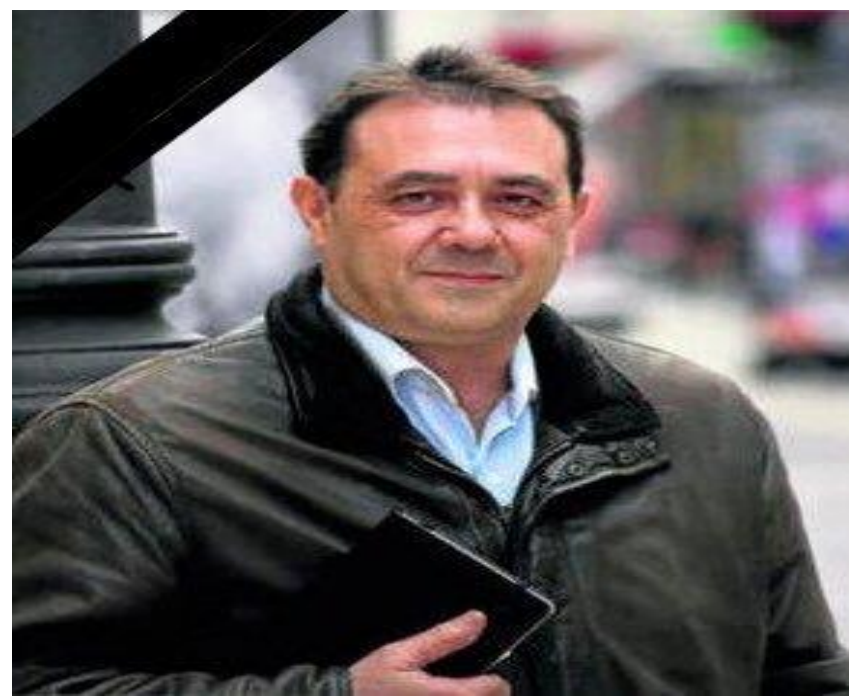

Todo empezó en la Universidad de Granada, en 1994. Fui a mi alma mater para formar parte de un tribunal de tesis doctoral. El trabajo cumplía sobradamente con las altas expectativas que caracterizaban al área de Lingüística General granadina en aquellos tiempos: novedad radical, riesgo intelectual, disciplina y método, una sugerente aventura científica. El director era Pedro San Ginés, quien ya entonces nos había sorprendido unas cuantas veces. Aparte de introducir la sinología en España, casi nada, Pedro ha sido siempre una mente profunda e inquieta, capaz de proyectar sus intereses disciplinares hacia ámbitos más amplios, siempre en la última frontera científica. Esta vez su doctorando presentaba una propuesta arriesgada, por extensa e inhabitual, fundamentada en la traductología, la filosofía y la semiótica. En el papel, un voluminoso texto que sin embargo se leía como una novela, lo había resuelto de manera brillante. El acto de defensa resultó incluso mejor, dando muestra de una solvencia y una agilidad inhabituales en quien se supone que está iniciando su trayectoria académica. Emilio Ortega Arjonilla, por supuesto, fue doctor con la máxima nota posible; también con una calificación intangible, la firme convicción de todos los presentes en aquel acto de que frente a nosotros había pasado un joven científico cargado de futuro.

Durante el acto de defensa de la tesis tuve la sensación de que podíamos haber invertido perfectamente los papeles que estábamos desempeñando en ese momento. A fin de cuentas, yo era solo unos pocos años mayor que el doctorando, con quien 
compartía grupo generacional. $Y$, visto su desempeño, tampoco hubiera sido algo extraño, o inopinado, que él me hubiera juzgado a mí. Desde luego, podía enseñarme muchísimas cosas. De manera que casi que estábamos predestinados a iniciar un diálogo científico y humano.

Lo confirmé de inmediato. Después de los rituales académicos, pude empezar a conocerlo de otra forma, quizá más profunda. El doctorando, Emilio, era un apasionado del conocimiento, una humanidad serena y afable que había puesto toda su enorme capacidad intelectual al servicio de la investigación. Lo había hecho sin cortapisas ni excusas, con una generosidad extensa y abarcadora. Además, había sido capaz de contextualizar de inmediato todo ese esfuerzo, para no perder ni por un instante la necesaria conexión con la vida y el mundo que lo rodeaba. Emilio nunca fue un profesional distante, encerrado en su maravillosa torre de marfil. Todo lo contario. Sintió profunda y finamente el mundo, al que en última instancia iban destinadas sus acciones como investigador y académico. Eso formaba parte también de la incuestionable brillantez que siempre transmitió. Emilio fue mucho más que un científico; fue además un humanista, un intelectual en el sentido más clásico y ejemplar del término.

Por supuesto que volví impresionado a Almería. Sería inexacto decir que contagié mi admiración a los colegas de la UAL. Emilio era admirado y apreciado sin intermediaciones, por sí mismo. Bastó con que, ya radicado en Málaga, visitara el campus almeriense, lo escucháramos hablar, nos trasladara sus proyectos, nos contagiara su entusiasmo, su optimismo innegociable. Desde el principio se instaló en nuestro imaginario, tanto en lo personal, como en lo profesional. Durante el último cuarto de siglo ha sido nuestro referente en traductología, al que hemos acudido con la absoluta certeza de que siempre nos iba a atender, de que inevitablemente terminaría sorprendiéndonos con una idea, un apunte, una investigación, fuera de la imaginación de los demás mortales.

Compartimos con él su impecable trayectoria académica. Profesor en la Universidad de Málaga desde 1995, catedrático de Traducción desde 2012, Emilio Ortega Arjonilla, no solo fue el demiurgo de la Facultad de Traducción en la UMA, sino que terminó convirtiéndose en un referente internacional en su materia. Eso sí, nunca renunció a la fórmula ejemplar que tuve la fortuna de conocer a través de su tesis: inteligencia excepcional, pero también enorme capacidad de trabajo, tenacidad y constancia infatigables.

Excuso decir que durante todos estos años hemos transitado la línea AlmeríaMálaga-Almería en innumerables ocasiones, embarcados en muchísimas singladuras profesionales. Con Emilio hemos intercambiado conferencias, hemos compartido tribunales, hemos organizado congresos, hemos diseñado proyecto de investigación conjuntos $y$, sobre todo, algo más valioso por intangible, hemos tenido la certeza de que siempre, en cualquier momento y circunstancia, podíamos contar con su generosidad y soporte. 
Cuando iniciamos el proyecto de Sabir. International Bulletin of Applied LInguistics, por supuesto, nos animó de inmediato y se ofreció a apoyar la publicación en lo que fuera necesario; como siempre, Emilio, sinónimo de bonhomía y solidaridad sin cortapisas. El caso es que antes de hablar con él ya me había ocupado de que formar parte del comité científico, por definición y por plena confianza en su capacidad profesional y en su compromiso humano. De hecho, estaba previsto contar con una contribución suya para el número 1 , con el que teníamos la intención de presentarnos a partir del pasado 15 de julio. Prácticamente un mes antes, el 14 de junio, nos llegó la noticia de su repentino fallecimiento. En ese momento decidimos cambiar el número y dedicarlo monográficamente a la traducción en homenaje a Emilio. Solo hemos pretendido que fuera un testimonio de gratitud, un reconocimiento hacia quien tanto y tan bien nos había acompañado en esta andadura por la vida académica, por la Vida sin adjetivos. Pensamos que la manera más genuina de hacerlo era transmitir nuestra modestia, la misma y contagiosa sencillez con la que nos visitaba Emilio. El catedrático laureado, el conferenciante reconocido en más de 50 países, el autor de referencia, sin embargo, nunca perdió la luz del entusiasmo que le conocí durante la defensa de su tesis doctoral, esa mirada franca durante sus intervenciones, a través de la que certificaba que, honestamente, creía lo que estaba diciendo.

De manera que en este número están las personas que, con diversos tipos de vinculación a la Universidad de Almería, han conocido y apreciado a Emilio Ortega Arjonilla. Para muchos de nosotros ha supuesto un esfuerzo trasladarnos desde nuestros dominios disciplinares a los de la traducción. Lo hemos hecho desde el recuerdo a nuestro entrañable amigo, pero también desde la convicción de que la interdisciplinariedad no deja de ser un reto que, en el caso de la mía, parte de la lingüística aplicada, probablemente para llegar desde ella a la descriptiva y la teórica. En eso Emilio y yo también estábamos de acuerdo, como en tantas otras cosas. 